\title{
Primary hyperoxaluria type 2
}

INSERM

\section{Source}

INSERM. (1999). Orphanet: an online rare disease and orphan drug data base. Primary

hyperoxaluria type 2. ORPHA:93599

Primary hyperoxaluria (PH) type 2 is a rare disorder of glyoxylate metabolism caused by the deficiency of the enzyme glyoxylate reductase/hydropyruvate reductase (GR/HPR) characterized by a childhood onset with clinical manifestations that include recurrent nephrolithiasis, nephrocalcinosis and end-stage renal disease with subsequent systemic oxalosis. 